\title{
Decomposition of the finest root branching orders: linking belowground dynamics to fine-root function and structure
}

\author{
Marc Goebel, ${ }^{1}$ Sarah E. Hobbie, ${ }^{2}$ Bartosz Bulaj,${ }^{3}$ Marcin Zadworny,${ }^{4}$ Douglas D. Archibald, ${ }^{5}$ \\ Jacek Oleksyn, ${ }^{4,6}$ Peter B. Reich, ${ }^{6}$ and David M. Eissenstat ${ }^{1,7}$ \\ ${ }^{1}$ Department of Horticulture and Intercollege Graduate Program in Ecology, Pennsylvania State University, \\ University Park, Pennsylvania 16802 USA \\ ${ }^{2}$ Department of Ecology, Evolution and Behavior, University of Minnesota, St. Paul, Minnesota 55108 USA \\ ${ }^{3}$ Department of Silviculture, University of Life Sciences in Poznan, 60-625 Poznan, Poland \\ ${ }^{4}$ Polish Academy of Sciences, Institute of Dendrology, Parkowa 5, 62-035 Kórnik, Poland \\ ${ }^{5}$ Department of Crop and Soil Sciences, Pennsylvania State University, University Park, Pennsylvania 16802 USA \\ ${ }^{6}$ Department of Forest Resources, University of Minnesota, St. Paul, Minnesota 55108 USA
}

\begin{abstract}
Root turnover is fastest in the finest roots of the root system (first root order). Additionally, tissue chemistry varies among even the finest root orders and between white roots and older, pigmented roots. Yet the effects of pigmentation and order on root decomposition have rarely been examined. We separated the first four root orders $($ all $<1 \mathrm{~mm})$ of four temperate tree species into three classes: white first- and second-order roots; pigmented first- and second-order roots; and pigmented third- and fourth-order roots. Roots were enclosed in litterbags and buried under their own and under a common species canopy in a 34year-old common garden in Poland. When comparing decomposition of different root orders over 36 months, pigmented third- and fourth-order roots with a higher $\mathrm{C}: \mathrm{N}$ ratio decomposed more rapidly, losing 20-40\% of their mass, than pigmented first- and second-order roots, which lost no more than $20 \%$. When comparing decomposition of roots of different levels of pigmentation within the same root order over 14 months, pigmented (older) first- and secondorder roots lost $\sim 10 \%$ of their mass, while white (younger) first- and second-order roots lost $\sim 30 \%$. In contrast to root mass loss, root $\mathrm{N}$ content declined more rapidly in the first- and second-order roots than in third- and fourth-order roots. In higher-order roots, $\mathrm{N}$ increased in the first 10 months from $\sim 110 \%$ to nearly $150 \%$ of initial $N$ content, depending on species; by the end of the study $\mathrm{N}$ content had returned to initial levels. These findings suggest that, in plant communities where root mortality is primarily of pigmented first- and second-order roots, microbial decomposition may be slower than estimates derived from bulk fine-root litterbag experiments, which typically contain at least four root orders. Thus, a more mechanistic understanding of root decomposition and its contribution to ecosystem carbon and nutrient dynamics requires a fundamental shift in experimental methods that stratifies root samples for decomposition along more functionally based criteria such as root order and pigmentation, which parallel the markedly different longevities of these different root classes.

Key words: Acer pseudoplatanus L.; biomass; decomposition; fine roots; Larix decidua Mill.; litterbags; nitrogen; Pinus sylvestris L.; root order; root pigmentation; Siemianice Experimental Forest, southwestern Poland; Tilia cordata Mill.
\end{abstract}

\section{INTRODUCTION}

While fine-root turnover may represent one-third to one-half of total plant tissue turnover (Caldwell 1987, Jackson et al. 1997), the fate of the finest roots after they die is poorly understood. Previous studies suggest that root decomposition is strongly influenced by tissue chemistry. For example, in a global meta-analysis of data in 32 publications (representing 30 study sites and decomposition of fine roots of over 20 conifer and broadleaf tree species), rates of fine-root decomposition were more closely linked to root tissue chemistry

Manuscript received 23 December 2009; revised 25 May 2010; accepted 25 June 2010; final version received 30 July 2010. Corresponding Editor: R. W. Ruess.

${ }^{7}$ Corresponding author. E-mail: dme9@psu.edu (specifically root $\mathrm{Ca}$ concentration and $\mathrm{C}: \mathrm{N}$ ratio) than to climatic or other environmental factors (Silver and Miya 2001). Root tissue chemistry explained greater than $85 \%$ of the variation in root decay rates, in both the initial and later phases of root decomposition. Important chemical properties linked to fine-root decomposition in temperate tree species include $\mathrm{Ca}$, lignin, and $\mathrm{N}$ concentrations; $\mathrm{C}: \mathrm{N}$, lignin: $\mathrm{N}$, and lignin: $\mathrm{P}$ ratios; and concentrations of water-soluble phenols (Berg 1984, Ostertag and Hobbie 1999, Silver and Miya 2001, Chen et al. 2002).

Variation in tissue chemistry and anatomy is functionally linked more to root branching order than to root diameter (Pregitzer et al. 2002, Guo et al. 2008a, Valenzuela-Estrada et al. 2008). Different root orders 
perform different sets of functions with higher orders (e.g., third, fourth, and higher) principally used in transport, storage, and structural support and lower orders (e.g., first and second) used mainly for nutrient and water acquisition (Guo et al. 2008a, ValenzuelaEstrada et al. 2008, 2009). These differences in function among root orders strongly influence tissue chemical properties, including $\mathrm{C}: \mathrm{N}$ ratio, and concentrations of total nonstructural carbohydrates, $\mathrm{Ca}$, phenolic compounds, suberin, and lignin (McKenzie and Peterson 1995a, b, Pregitzer et al. 2002, Guo et al. 2004, Leuschner et al. 2004, Soukup et al. 2004, Fan and Guo 2010). In Pinus palustris for example, first-order roots (mean diameter $=0.35 \mathrm{~mm}$ ) had approximately fourfold higher $\mathrm{N}$ concentration than fourth-order roots (mean diameter $=0.79 \mathrm{~mm}$ ) (control plots; Guo et al. 2004). Moreover, root order also strongly influences life span, with life span increasing by root order such that third- and fourth-order roots more often are semipermanent members of the root system (Eissenstat et al. 2000, Wells and Eissenstat 2001, Guo et al. 2008a, $b$ ). Consequently, the first- and secondorder roots that most frequently die and that are chemically distinct from the third- and fourth-order roots may decompose at different rates from these higherorder roots; yet typical "fine"-root decomposition studies with a diameter cutoff of less than 1 or $2 \mathrm{~mm}$ likely include at least four root orders (Pregitzer et al. 2002, Guo et al. 2004, 2008a).

Rarely have studies of root decomposition accounted for potentially important variation in tissue chemistry among fine-root diameter classes or branching orders within the root system, and even fewer have focused on the finest, lowest-order roots that dominate root turnover. An exception is a study by Fan and Guo (2010) that revealed that despite a higher $\mathrm{C}: \mathrm{N}$ ratio in higher-order than lower-order roots, the lower-order (orders 1 and 2) roots decomposed more slowly over a $500-d$ period in two tree species in forest plantations in northeastern China. They also found total nonstructural carbohydrate concentration to be positively correlated with rates of decomposition.

In addition to root order, another important source of variation in root chemistry is pigmentation. During a growing season, flushes of fine-root growth can occur in distinct periods (Engler 1903, Krueger and Trappe 1967, Lyr and Hoffmann 1967, King et al. 2002), resulting in discrete subpopulations of first- and second-order roots that are slightly older and pigmented vs. younger and unpigmented ("white") roots. To our knowledge, roots always begin white and change color on the order of days to months, depending on the species and the environment (Comas et al. 2000, Wells and Eissenstat 2003, Withington et al. 2006). The change in color usually represents changes in tissue chemistry, anatomy, and mycorrhizal colonization (Comas et al. 2000, Wells and Eissenstat 2003). Younger, white first- and secondorder roots may have much lower $\mathrm{C}: \mathrm{N}$ ratio, concentrations of phenolic compounds, and secondary wall development than pigmented roots that may be only one month older (Eissenstat and Volder 2005, Volder et al. 2005). Young, white roots may also be particularly vulnerable to predation and parasitism because of their limited defenses (Bauerle et al. 2007, Resendes et al. 2008). Thus, roots that die when young and still unpigmented may decompose at different rates than those that die at a later pigmented stage, contributing to variation in rates of carbon and nutrient cycling. While white roots are vulnerable to herbivory, a large fraction of white roots damaged by herbivores may not actually pass through the gut of the organisms and thus follow a more typical path of microbial decomposition (Bauerle et al. 2007, Resendes et al. 2008).

The main objective of this study was to determine the effect of root order and root pigmentation on root tissue chemistry and rates of decomposition among four widespread and important European temperate tree species that vary widely in tissue traits (e.g., root $\mathrm{Ca}$ concentrations, mycorrhizal type; Hobbie et al. 2006, Dauer et al. 2007). To address the effects of root order, we contrasted rates of decay among pigmented first- and second-order roots with those of pigmented third- and fourth-order roots. Lower-order roots typically have smaller diameters, higher $\mathrm{N}$ and $\mathrm{P}$ concentrations, lower lignin concentrations, lower nonstructural carbohydrate concentrations, and higher mycorrhizal colonization levels than do higher-order roots (Peterson et al. 1999, Leuschner et al. 2003, Hishi 2007, Guo et al. 2008a, Valenzuela-Estrada et al. 2008, Fan and Guo 2010). Pigmented third and fourth higher-order roots are more likely to develop secondary vascular tissues, including larger portions of xylem elements with lignified secondary walls, and loss of the cortex and associated mycorrhizas with secondary growth (Esau 1965, Brundrett et al. 1990, Massicotte et al. 1999, Guo et al. $2008 a$ ). If decomposition was primarily driven by $C: N$ ratio (as commonly seen more generally; Silver and Miya 2001), than we would expect that first- and secondorder roots would decompose faster than third- and fourth-order roots.

We also expected root pigmentation to affect rates of decomposition. Compared to older, pigmented first- and second-order roots, younger, white first- and secondorder roots typically have lower concentrations of condensed tannins, less secondary wall development with less lignin and suberin deposition, and lower C:N ratios (Peterson et al. 1999, Comas et al. 2000; Volder et al. 2005). Because of these differences, we hypothesized that white fine roots would decompose more rapidly than roots of similar order that are pigmented.

\section{Methods}

\section{Site description}

The experiment was established in the common garden "Morawina" of the Siemianice Experimental Forest near the village of Biadaszki in southwestern Poland $\left(51^{\circ} 14.87^{\prime} \mathrm{N}, 18^{\circ} 06.35^{\prime} \mathrm{E}\right.$, elevation $\left.150 \mathrm{~m}\right)$. We 
examined root decomposition of four temperate tree species of 14 growing at that site: sycamore maple (Acer pseudoplatanus L.), small-leafed lime (Tilia cordata Mill.), European larch (Larix decidua Mill.), and Scots pine (Pinus sylvestris L.). The species differ in numerous ways at tissue and plant scales, including their litter $\mathrm{Ca}$ content, which has been linked to rates of forest floor turnover (Reich et al. 2005, Hobbie et al. 2006). Each single-species plot of the four tree species was $20 \times 20 \mathrm{~m}$ and replicated three times. Local weather conditions were influenced by the maritime and continental climate with a long-term average annual precipitation of 591 $\mathrm{mm}$ and a long-term mean annual air temperature of $8.2^{\circ} \mathrm{C}$ (Reich et al. 2005). During the time of our decomposition experiment, mean annual air temperature was $7.5^{\circ} \mathrm{C}$, with mean monthly maximum of $23.5^{\circ} \mathrm{C}$ and a mean monthly minimum of $-11^{\circ} \mathrm{C}$. Buried data loggers (HOBO $8 \mathrm{~K}$, Onset Computer, Bourne, Massachusetts, USA) recorded soil temperature in the center of one plot of each of the four tree species for the first 20 months of the study. From July 2004 until February 2006, mean soil temperature at a depth of $10 \mathrm{~cm}$ was $8.3^{\circ} \mathrm{C}\left(-1.9^{\circ} \mathrm{C}\right.$ hourly minimum and $19.9^{\circ} \mathrm{C}$ hourly maximum). The relatively infertile soil of the common garden varied from a gray-brown podzolic to a brown podzolic soil (Spodosol U.S. Soil Taxonomy), the latter being less fertile (Withington et al. 2003). Soil pH of the $\mathrm{O}$ horizon in the plots of the four tree species varied from 4.0 (Pinus) to 6.1 (Tilia), while soil $\mathrm{pH}$ was less variable in the upper mineral horizon $(0-20 \mathrm{~cm})$, ranging from 4.0 (Pinus) to 5.0 (Acer) (Reich et al. 2005). Further information about the soil characteristics of the common garden can be found in Hobbie et al. (2006, 2007).

\section{Plant material}

Because the amount of first- and second-order roots that were needed for the decomposition studies $(2.2 \mathrm{~g}$ dry mass) could not be acquired in these long-term plots without excessive disturbance (more than 50 5-cmdiameter, 20-cm-length cores for at least three of the species would have been required), we used plants from local nurseries for root material. We acquired seedlings of two broadleaf tree species (Tilia cordata, Acer pseudoplatanus) from one local nursery and two coniferous tree species (Pinus sylvestris, Larix decidua) from a different local nursery in July 2004. Immediately after removal from the nursery, individual root systems were separated from the two- and three-year-old tree seedlings and soaked in 3-L, water-filled containers to remove bulk soil and to avoid the loss of the finest roots. The three ectomycorrhizal tree species ( $T$. cordata, $P$. sylvestris, L. decidua) were all colonized by ectomycorrhizal fungi (Appendix A: Table A1). For the arbuscular mycorrhizal, A. pseudoplatanus (Withington et al. 2003), mycorrhizas were not assessed. Root orders were identified by the morphometric approach, as described by Fitter (1982) and refined by Pregitzer et al. (2002) and collected from 4-8 cm long fine-root segments, using stand-alone magnifying glasses and tweezers. We combined pigmented first- and second-order roots into one class and pigmented third- and fourth-order roots (root diameter $<1 \mathrm{~mm}$ ) into a second class from $\sim 15$ tree seedlings per species, in order to collect enough root mass for a three-year study. In addition, for $A$. pseudoplatanus and $T$. cordata there were sufficient white fresh first- and second-order roots to form a third class. Thus, we had three fine-root classes: fresh growth (white) first- and second-order roots, $[1+2 \mathrm{~W}]$; pigmented (brown) first- and second-order roots, $[1+$ $2 \mathrm{~B}]$; and third- and fourth-order pigmented roots, $[3+4$ B]. All fine roots were oven-dried at $65^{\circ} \mathrm{C}$ to constant mass. Approximately $100 \mathrm{mg}$ of sample material of each root class were then sealed into their own $5 \times 10 \mathrm{~cm}$ compartment in one Ankom Forage bag (size $10 \times 20$ $\mathrm{cm}$, nitrogen-free polyester, mesh size $50 \mu \mathrm{m}$, Ankom Technology, Macedon, New York, USA).

For the study of root order, five root litterbags (RLB) were buried in August 2004 in a horizontal orientation at a depth of $8-13 \mathrm{~cm}$ in the center of each of the three replicate, monospecific tree species plots of the same species as the nursery seedlings ("own" plots). A different RLB of each tree species plot was recovered after 3, 8, 14, 19, and 36 months (three RLB in total for each harvest). We used the remaining fine-root-order material and buried three additional RLB for each of the four tree species, also replicated three times, under a common-species canopy (Acer platanoides L.) ("common" plots). A different RLB of each tree species under the common canopy was recovered after 3, 8, and 14 months, yielding three RLB in total per species for each harvest.

The study of the effects of root pigmentation on root decomposition was limited by availability of root material; therefore we examined decomposition of $[1+$ $2 \mathrm{~W}]$ roots only in their own plots over a time period of 14 months for two species, A. pseudoplatanus and $T$. cordata. Root bags were installed in August 2004 in a similar orientation as previously described, harvested at 3, 8, and 14 months, and compared with pigmented roots of the same order.

At each harvest date, root litter bags were again ovendried at $65^{\circ} \mathrm{C}$ to constant mass, and root-order segments were collected for weighing. Because root segments were still intact, complete removal was straightforward. A portion $(5 \mathrm{mg})$ of the roots from each of the three recovered root litter bags from the three different plots $(n=3)$ were used to determine $\mathrm{C}$ and $\mathrm{N}$ concentrations with an elemental analyzer (Fisons EA 1108; Fisons Instruments, Dearborn, Michigan, USA). A second portion ( $5 \mathrm{mg}$ ) was used to determine $\mathrm{Mg}, \mathrm{Ca}, \mathrm{Al}$, and $\mathrm{P}$ concentrations by inductively coupled plasma-atomic emission spectrometry (ICP) after samples were dryashed $\left(500^{\circ} \mathrm{C}\right)$ and resuspended in a $1 \mathrm{~mol} / \mathrm{L} \mathrm{HCl}$ matrix (Agricultural Analytical Service Laboratory, University Park, Pennsylvania, USA). A third portion (5 mg) was 
TABLE 1. The effects of root order on initial tissue chemistry at the start of the litterbag experiment in four temperate tree species: Acer pseudoplatanus L., Tilia cordata Mill., Larix decidua Mill., and Pinus sylvestris L.

\begin{tabular}{|c|c|c|c|c|c|c|c|c|}
\hline Species & Root order & $\mathrm{C}$ & $\mathrm{N}$ & Lignin & $\mathrm{Al}$ & $\mathrm{Ca}$ & $\mathrm{Mg}$ & $\mathrm{P}$ \\
\hline \multirow[t]{2}{*}{ Acer pseudoplatanus } & & $488(0.2)$ & $15.8(0.4)$ & $227(8.5)$ & $1.15(0.1)$ & $6.2(0.3)$ & $3.1(0.2)$ & $1.8(0.1)$ \\
\hline & & 493 (6.6) & $9.9(0.6)$ & 229 (39) & $0.45(0.0)$ & $7.3(0.3)$ & $1.6(0.0)$ & $1.6(0.1)$ \\
\hline \multirow[t]{2}{*}{ Tilia cordata } & {$[1+2 \mathrm{~B}]$} & $490(2.0)$ & $16.3(0.5)$ & 189 (54) & $1.47(0.1)$ & $14(0.7)$ & $2.5(0.1)$ & $2.0(0.1)$ \\
\hline & $4 \mathrm{~B}]$ & $487(9.2)$ & $8.6(0.3)$ & 247 (63) & $0.51(0.0)$ & $7.1(0.9)$ & $1.7(0.1)$ & $1.1(0.1)$ \\
\hline \multirow[t]{2}{*}{ Larix decidua } & {$[1+2 \mathrm{~B}]$} & $449(0.3)$ & $18.9(0.0)$ & $176(29)$ & $9.44(0.3)$ & $7.6(1.1)$ & $1.9(0.1)$ & $5.2(0.1)$ \\
\hline & {$[3+4 \mathrm{~B}]$} & $482(1.3)$ & $11.8(0.2)$ & $200(55)$ & $7.21(0.4)$ & $6.5(0.2)$ & $1.9(0.1)$ & $2.6(0.1)$ \\
\hline \multirow[t]{2}{*}{ Pinus sylvestris } & {$[1+2 \mathrm{~B}]$} & $434(6.9)$ & $18.0(0.9)$ & $102(22)$ & $9.93(0.3)$ & $7.4(0.5)$ & $1.9(0.1)$ & $5.5(0.2)$ \\
\hline & {$[3+4 B]$} & 475 (17) & $19.1(0.5)$ & 129 (22) & $7.86(0.2)$ & $9.7(0.5)$ & $2.5(0.1)$ & $5.2(0.1)$ \\
\hline
\end{tabular}

Notes: Data are expressed as milligrams per gram (with SE in parentheses; $n=3$ ) of root dry mass of two root order classes: pigmented first- and second-order roots $[1+2 \mathrm{~B}]$ and pigmented third- and fourth-order roots $[3+4 \mathrm{~B}]$ of the four temperate tree species. The experiment was established in the common garden "Morawina" of the Siemianice Experimental Forest near the village of Biadaszki in southwestern Poland.

used for lignin determination by a modified acetyl bromide method (Iiyama and Wallis 1988, Brinkmann et al. 2002) after removing esterified phenolics and lipids. Root mass and lignin concentration are reported on an ash-free dry-mass basis.

Since root segments of root branching orders showed limited superficial signs of decay, $[1+2 \mathrm{~B}]$ and $[3+4 \mathrm{~B}]$ roots of the species were investigated for internal decay of the root structures from the root litter bags after 19 and 36 months of decomposition. Root segments of $\sim 1$ $\mathrm{cm}$ length of the different branching orders were embedded in Paraplast plus (Sigma Chemical, St. Louis, Missouri, USA), after fixation and dehydration, to obtain $10-\mu \mathrm{m}$ root-order cross sections, using an American Optics microtome (Warner-Lambert Technologies, Buffalo, New York, USA). Cross sections were stained in $0.5 \%$ toluidine blue $\mathrm{O}$ in $1 \%$ sodium tetra borate according to O'Brien et al. (1968). Digital microscope images of root cross sections, embedded in Canadian Balsam, were taken under an Olympus BX61 Epi-Fluorescence Microscope (Olympus America, Center Valley, Pennsylvania, USA) at the Cytometry Facility at the Huck Institutes of the Life Sciences at Pennsylvania State University, University Park, Pennsylvania, USA.

\section{Calculations and statistics}

We analyzed the effects of root order and root pigmentation on initial tissue chemistry concentrations and ratios in the four temperate tree species with ANOVA. Percentage of remaining ash-free dry mass relative to the initial dry mass was determined for each harvest. We calculated the decay constant $(k)$ of each root class across plots by fitting the proportion of massremaining data of each root class to a single, negative exponential decay model:

$$
X=e^{-k t}
$$

where $X$ is the proportion of the initial biomass remaining at time $t$ and $k$ is the decay constant (Wieder and Lang 1982) using nonlinear least-squares fitting. Stepwise multiple regression with backward elimination was used to identify how well initial root tissue chemical characteristics and root pigmentation class explained variation in $k$ among root classes. Prior to regression, we tested for significant autocorrelation among initial root characteristics by pairwise correlation $(P<0.05$ and $r>$ 0.80 ). Significance of $k$ and remaining root mass was tested among root classes and species (both categorical variables) with an analysis of covariance (ANCOVA) with time (continuous variable) as the covariate. All statistical analyses were conducted using JMP statistical software (version 7.0; SAS, Cary, North Carolina, USA).

\section{Results}

\section{Root order}

As expected, the initial chemical composition differed among roots of different order prior to their placement in litter bags (Table 1). Nutrient concentrations were generally higher in $[1+2 \mathrm{~B}]$ roots than $[3+4 \mathrm{~B}]$ roots. For example, $\mathrm{N}$ concentration in lower-order [1+2 B] roots was almost twice that of higher-order $[3+4 \mathrm{~B}]$ roots for A. pseudoplatanus, T. cordata, and L. decidua,

TABLE 2. Probability values from an analysis of variance (ANOVA) of root order on initial tissue chemistry at start of litterbag experiment in four temperate tree species of initial chemical concentrations or ratios.

\begin{tabular}{|c|c|c|c|c|c|c|c|c|c|c|c|}
\hline Factor & $\mathrm{C}$ & $\mathrm{N}$ & Lignin & $\mathrm{Al}$ & $\mathrm{Ca}$ & $\mathrm{Mg}$ & $P$ & $\mathrm{C}: \mathrm{N}$ & Lignin: $\mathrm{N}$ & Lignin:P & $\mathrm{Ca}: \mathrm{Al}$ \\
\hline & & & & & Co. & & & & & & \\
\hline & & & 0.97 & & & $<0.0001$ & & $<0.0001$ & & & $<0.0001$ \\
\hline root order & 0.033 & $<0.0001$ & 0.92 & 0.011 & $<0.0001$ & $<0.0001$ & $<0.0001$ & $<0.0001$ & 0.0009 & 0.041 & $<0.0001$ \\
\hline
\end{tabular}

Note: Roots were of two root order classes: pigmented, first- and second-order roots [1+2 B] and pigmented third- and fourthorder roots $[3+4 \mathrm{~B}]$ of four temperate tree species (Acer pseudoplatanus L., Tilia cordata Mill., Larix decidua Mill., and Pinus sylvestris L.; $n=3$ root litterbags per sampling time). Boldface indicates $P<0.05$; italics indicate $P<0.10$. 
TABLE 1. Extended.

\begin{tabular}{lrcc}
\hline \hline C:N & Lignin:N & Lignin:P & Ca:Al \\
\hline $31(0.8)$ & $14(0.7)$ & $127(13)$ & $5(0.2)$ \\
$50(2.7)$ & $23(5.1)$ & $138(23)$ & $16(1.6)$ \\
$30(0.9)$ & $11(3.7)$ & $93(30)$ & $9.9(0.5)$ \\
$56(1.7)$ & $28(7.6)$ & $213(47)$ & $14(0.8)$ \\
$23(0.1)$ & $9(1.5)$ & $33(6)$ & $0.82(0.1)$ \\
$41(0.8)$ & $16(4.5)$ & $78(24)$ & $0.90(0.03)$ \\
$24(1.0)$ & $6(1.4)$ & $18(5)$ & $0.74(0.03)$ \\
$25(0.9)$ & $7(1.0)$ & $24(4)$ & $1.23(0.03)$
\end{tabular}

but not for $P$. sylvestris (species $\times$ root-order interaction, $P<0.0001)$. Of the chemical characteristics measured, lignin was not affected by root order (Table 2; order effect, $P>0.97$ or species $\times$ order effect, $P>0.92$ ). In general, $P$. sylvestris showed the smallest differences in tissue chemistry among root orders. When comparing the initial chemistry of the roots placed in the litterbags that were derived from nursery trees (Table 1) with that of the trees in the common garden (Appendix B), concentrations of $\mathrm{N}, \mathrm{P}, \mathrm{Ca}$, and $\mathrm{Mg}$ were generally higher and $\mathrm{Al}$ concentration lower in the roots of the nursery seedlings. Patterns of higher $\mathrm{N}$ and $\mathrm{P}$ concentrations in lower-order than higher-order roots observed in the nursery seedlings, however, were similar to those occurring in the roots of the common garden trees.
Initial tissue chemical parameters of the litter bag roots were more highly intercorrelated with decomposition for lower-order (first- and second-order) roots than for higher-order (third- and fourth-order) roots (Appendix C). In third- and fourth-order roots, many chemical parameters were significantly correlated. For example, initial $\mathrm{Mg}$ concentration was positively correlated to initial $\mathrm{N}(r=0.93), \mathrm{P}(r=0.94), \mathrm{Al}(r=0.80)$, and $\mathrm{Ca}(r=0.84)$ and negatively correlated with $\mathrm{Ca}: \mathrm{Al}$ ratio $(r=-0.73)$. However, in first- and second-order pigmented roots, $\mathrm{Mg}$ was negatively correlated with $\mathrm{N}$ $(r=-0.74), \mathrm{P}(r=-0.84)$, and $\mathrm{Al}(r=-0.85)$ but was positively correlated with $\mathrm{Ca}: \mathrm{Al}$ ratio $(r=0.58)$.

Despite their higher $\mathrm{C}: \mathrm{N}$ ratio and larger diameter (lower surface: mass ratio), higher-order [3+4 B] roots decomposed faster than lower-order $[1+2 \mathrm{~B}]$ roots, as reflected by significant time, order, or order $\times$ time effects (Fig. 1). This was true under their own- and common-species canopies. Under their own-species canopy, A. pseudoplatanus and $T$. cordata showed the greatest differences in rates of decomposition between root-order classes. Higher-order $[3+4 \mathrm{~B}]$ roots of both species lost $\sim 2.5$ times as much of their initial mass than lower-order [ $1+2 \mathrm{~B}]$ roots. In contrast, $L$. decidua mass loss of higher-order [3+4 B] roots was 1.75 times greater than in lower-order [1 $+2 \mathrm{~B}]$ roots, with a difference of only $15 \%$ between root orders for P. sylvestris. Under

Own-species canopy

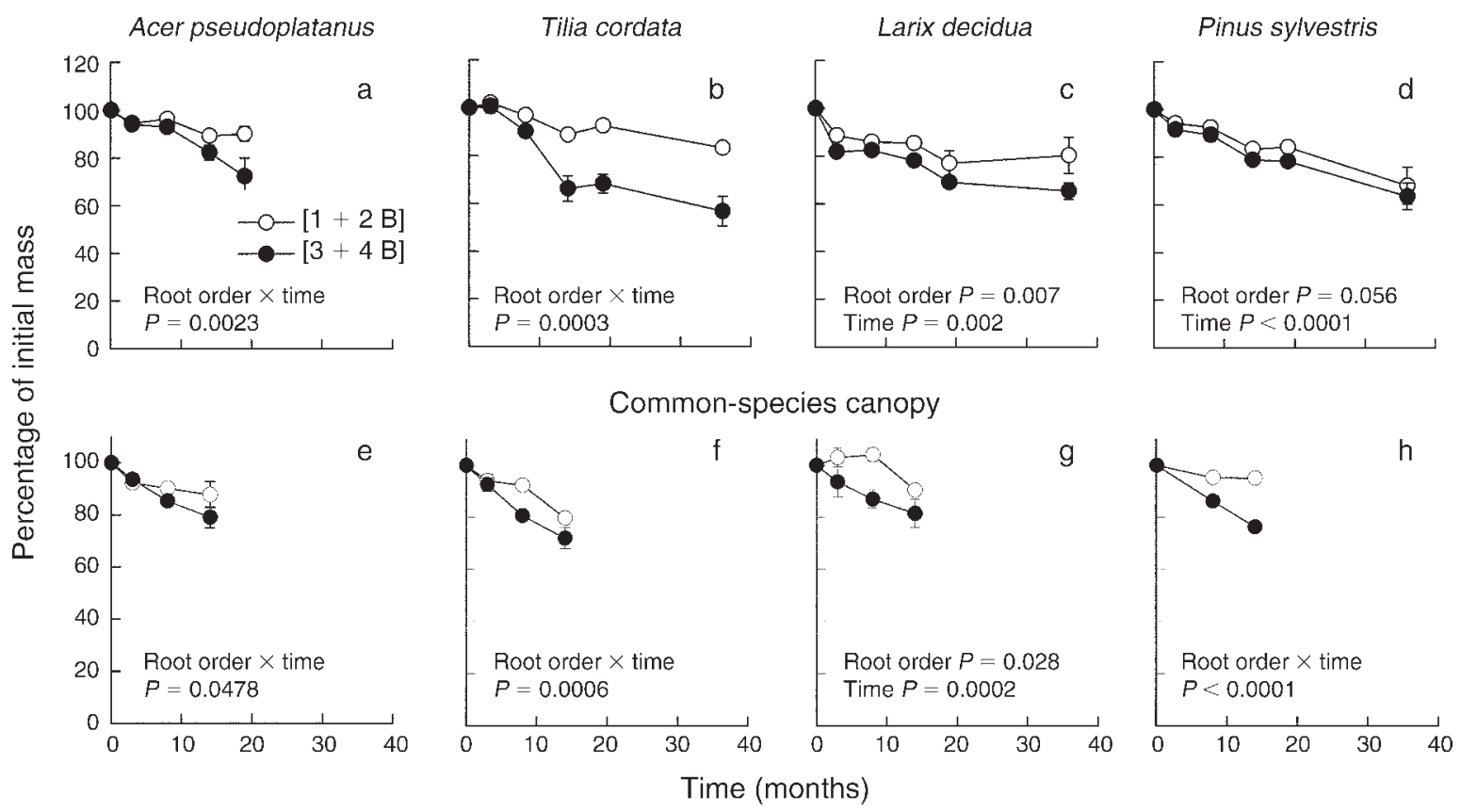

FIG. 1. Effects of root branching order on biomass during decomposition. Data are expressed as percentage of initial mass under the $(\mathrm{a}-\mathrm{d})$ own-species canopy and $(\mathrm{e}-\mathrm{h})$ a common-species canopy for four tree species. Pigmented first- and second-order roots $[1+2 \mathrm{~B}]$ and pigmented third- and fourth-order roots $[3+4 \mathrm{~B}]$ represent roots of different root order class, from root litterbags placed at 10-cm soil depth and harvested after 3, 8, 14, 19, and 36 months for the own-species canopy placement and after 3,8 , and 14 months under the common-species canopy placement. Error bars represent $\pm \mathrm{SE}(n=3$ root litterbags per sampling time, including the different root classes). The experiment was established in the common garden "Morawina" of the Siemianice Experimental Forest near the village of Biadaszki in southwestern Poland. 

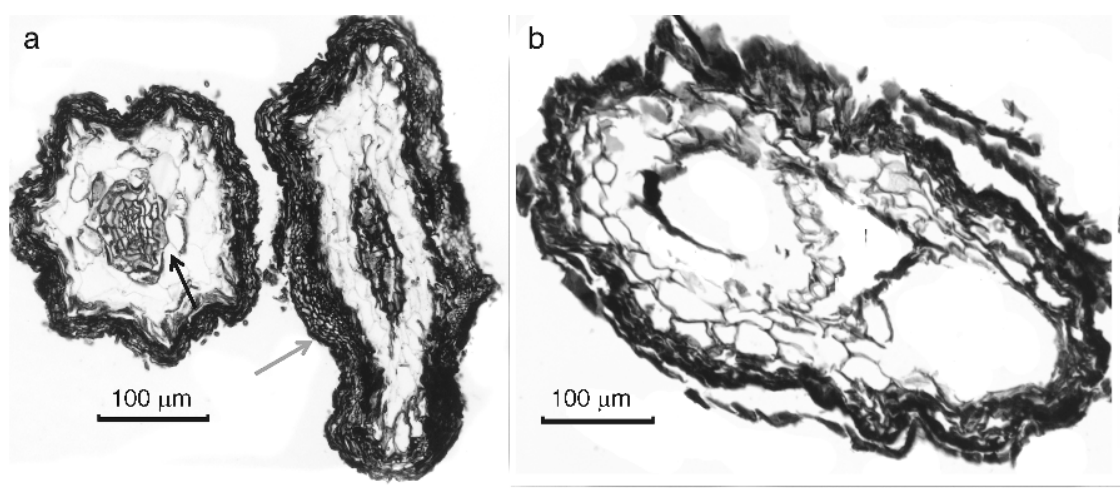

C
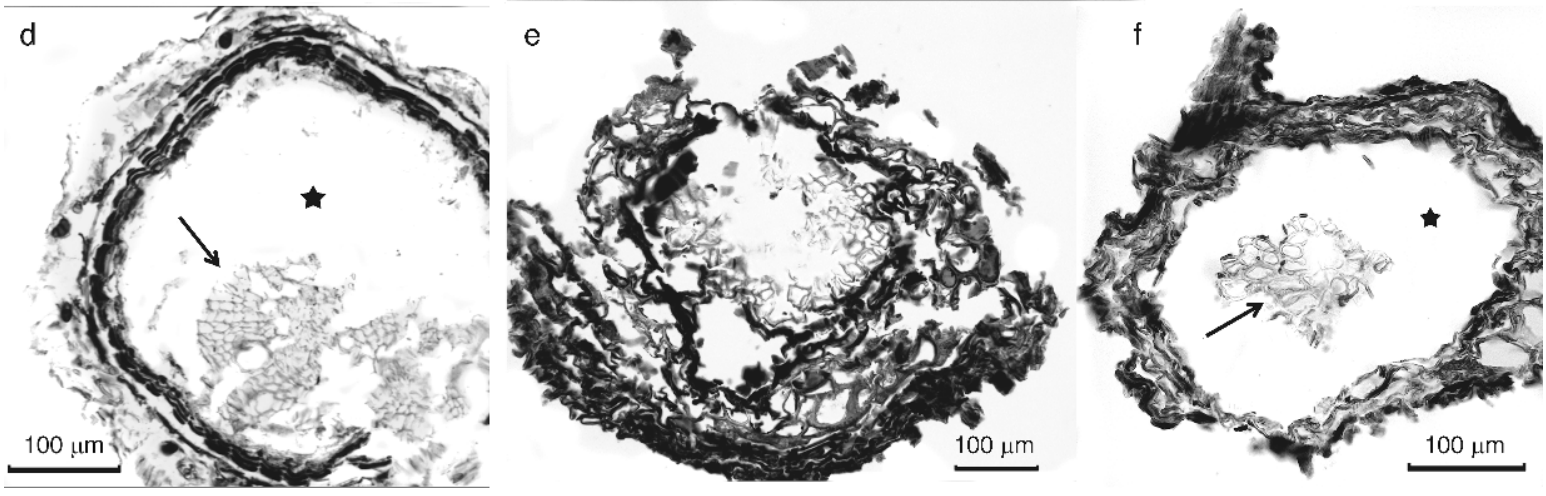

FIG. 2. Cross sections of pigmented (a-c) first- and second-order roots and (d-f) third- and fourth-order roots of Tilia cordata, Larix decidua, and Pinus sylvestris (left to right) after 36 months of decomposition. (a) Tilia cordata first- and second-order roots exhibited intact cell walls of endodermis (black arrow) and thick mycorrhizal fungal mantle (gray arrow). (d,f) Tilia cordata and Pinus sylvestris third- and fourth-order roots had only remnants of xylem elements (arrow) and no cell walls visible between the outer part of bark and xylem remnants (star). (b, e) Larix decidua shows an intermediate state of decay of both root orders.

the common-species canopy, a similar significant effect of root-order mass loss was observed for A. pseudoplatanus, $T$. cordata, and $L$. decidua, while $P$. sylvestris showed a more significant order $\times$ time effect for the initial 14 months, in contrast to its mass loss under its own-species canopy.

Anatomical transverse cross sections of root-order segments in the litterbags of all four species after 19 months of decomposition revealed relatively high structural integrity in both the lower and higher-order roots (Appendix D). In contrast, after 36 months of decay, many root structures had clearly decomposed (Fig. 2). In Tilia, structures in roots of the $[1+2 \mathrm{~B}]$ root class were reasonably intact, while the $[3+4 \mathrm{~B}]$ root class showed considerable degradation of the secondary xylem (Fig. 2a, d). In cross sections of Larix and Pinus roots, structural loss was apparent in both root order classes after 36 months of decomposition.

The single, negative exponential model described the actual rates of mass loss well for roots of the two root order classes using own-species plots. The estimated mass remaining fit the actual mass remaining for $[1+2$ B] roots with an $R^{2}=0.56(n=69)$ and in $[3+4 \mathrm{~B}]$ roots with an $R^{2}=0.75(n=69)$. The intercepts $\left(b_{0}\right)$ of the regressions between the estimated and the actual mass remaining underestimated the actual rate of decay $\left(b_{0}=\right.$ 5.5 for $[1+2 \mathrm{~B}]$ roots, $b_{0}=29$ for $[3+4 \mathrm{~B}]$ roots). Over the time period of 36 months, the decomposition constant $(k)$ was 0.10 for the $[1+2 \mathrm{~B}]$ roots and 0.19 for $[3+4 \mathrm{~B}]$ roots (Table 3 ). The predicted rates of decay for both the individual root order classes and the combined root order classes $([1+2 \mathrm{~B}]$ and $[3+4 \mathrm{~B}])$ were negatively related to initial $\mathrm{Mg}$ concentrations $(P<$ $0.001)$ and positively related to initial $\mathrm{P}$ concentrations $(P<0.001)$, with $R^{2}$ ranging from 0.21 to 0.28 . This was also the case when combining the root litter quality parameters with the categorical parameter root order class, which did not lead to an increase in the coefficient of determination $\left(R^{2}=0.28\right)$. Initial root $\mathrm{Mg}$ was negatively correlated with initial root $\mathrm{Ca} A \mathrm{Al}$ and positively correlated to initial root $\mathrm{Al}$ (Appendix C). However, exchanging $\mathrm{Mg}$ with $\mathrm{Al}$ greatly weakened the description of predicted rates of decay $\left([1+2 \mathrm{~B}], R^{2}=\right.$ $\left.0.07 ;[3+4 \mathrm{~B}], R^{2}=0.04\right)$. Additionally, $\mathrm{P}$ and $\mathrm{Mg}$ were significant covariates when run in the ANCOVA model based on percentage mass loss (analyses not shown).

In contrast to root mass, root $\mathrm{N}$ content declined more rapidly in the lower-order $[1+2 \mathrm{~B}]$ roots than in the higher-order [3 +4 B] roots (Fig. 3), especially in earlier stages of decomposition under their own-species 
TABLE 3. Final models resulting from stepwise regressions of the root decomposition coefficient, $k$, against root chemical characteristics by root order class.

\begin{tabular}{|c|c|c|c|c|}
\hline Fine-root order classes & $k$ & $\mathrm{df}$ & $R^{2}$ & Model equation \\
\hline \multicolumn{5}{|l|}{ Chemical properties only } \\
\hline$[1+2 \mathrm{~B}]$ & 0.10 & 69 & 0.23 & $k=0.11-0.07 \times(\mathrm{Mg})+0.02 \times(\mathrm{P})$ \\
\hline$[3+4 \mathrm{~B}]$ & 0.19 & 69 & 0.28 & $k=0.25-0.17 \times(\mathrm{Mg})+0.05 \times(\mathrm{P})$ \\
\hline Combined & 0.15 & 138 & 0.21 & $k=0.19-0.11 \times(\mathrm{Mg})+0.03 \times(\mathrm{P})$ \\
\hline Root order class + chemical properties & 0.15 & 138 & 0.28 & $k=0.13-0.10 \times(\mathrm{Mg})+0.38 \times(\mathrm{P})+0.08 \times($ root order class $)$ \\
\hline
\end{tabular}

Notes: Results are separated into fine-root orders: pigmented first- and second-order roots [1+2 B]; pigmented third- and fourthorder roots [3+4 B]; first- and second- and third- and fourth-order roots (combined); and root order classes + chemical properties. All terms included in the models were significant at $P<0.001$.

canopy. Moreover, in the higher-order roots, $\mathrm{N}$ increased in the first 10 months from $\sim 110 \%$ of initial content in P. sylvestris to nearly $150 \%$ of initial content in T. cordata. Even after 19 months for A. pseudoplatanus and 36 months for T. cordata, L. decidua, and P. sylvestris, $\mathrm{N}$ content was similar to initial levels and generally similar between root order classes. Under the common-species canopy, $\mathrm{N}$ content showed a similar initial $\mathrm{N}$ increase in higher-order $[3+4 \mathrm{~B}]$ roots as under the own-species canopy.

The effects of root order on patterns of nutrient loss of $\mathrm{P}, \mathrm{Mg}$, and $\mathrm{Ca}$ were not consistent across species or between common and own plots (Appendix E). In $A$. pseudoplatanus and $P$. sylvestris, root order had essentially no effect on P loss, whereas in L. decidua, loss was generally more rapid in the $[1+2 \mathrm{~B}]$ root orders. In $T$. cordata, the effect of root order on $\mathrm{P}$ loss reversed from common to own plot. In general, the $\mathrm{Mg}$ content declined rapidly and similarly in both root order classes over time under the own- and common-species canopy, with losses of $30-80 \%$ of initial $\mathrm{Mg}$ pools during the first three months of decay, under the own and common canopy, respectively. Calcium content was only affected by root order in $T$. cordata, with higher-order roots exhibiting greater accumulation than the lower-order roots over time.

\section{Root pigmentation}

In contrast to our expectations, several key aspects of initial root tissue chemistry were similar among first- and

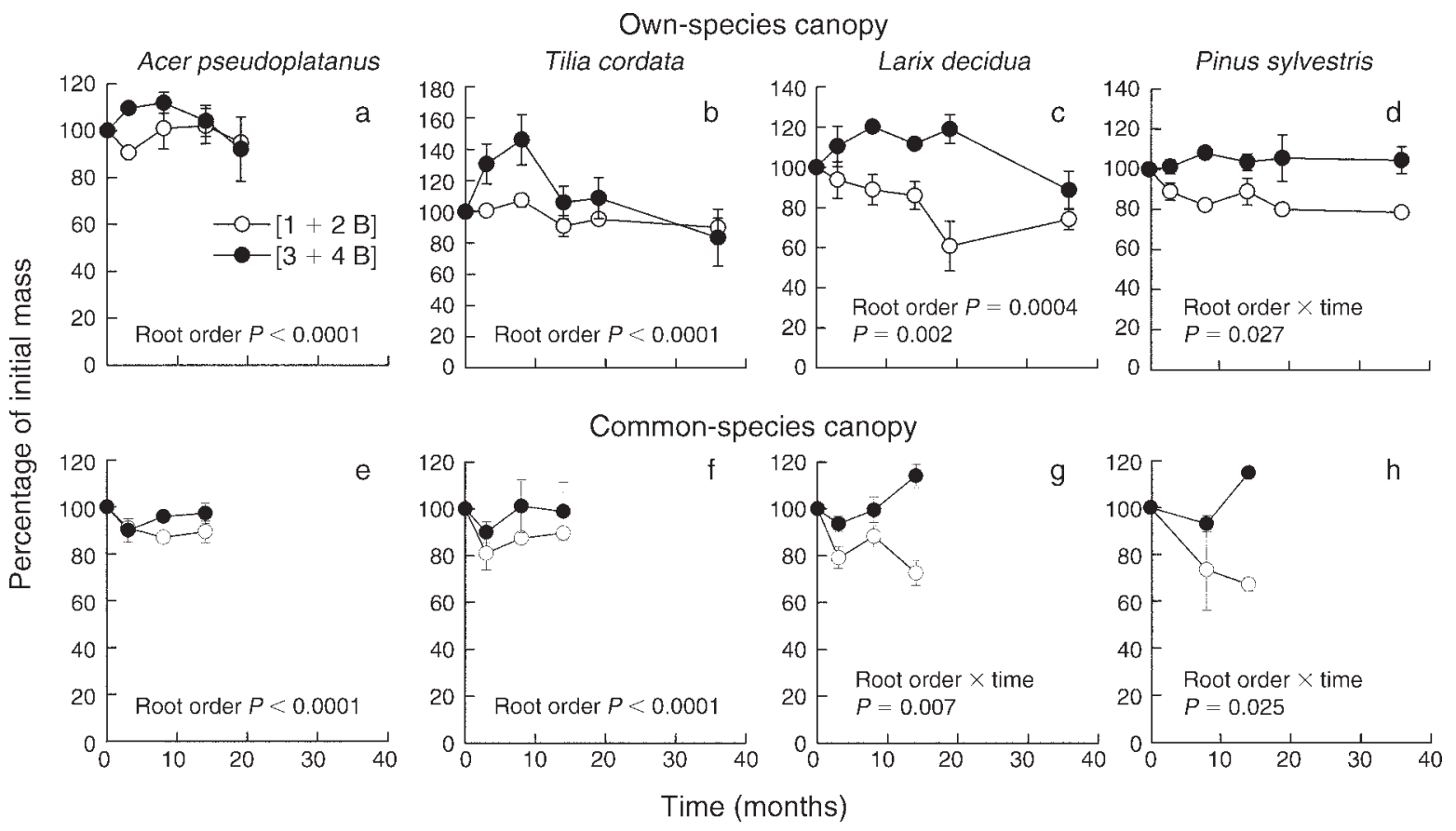

FIG. 3. Effects of root branching order on nitrogen content during decomposition. Data are expressed as percentage of initial nitrogen under $(\mathrm{a}-\mathrm{d})$ the own-species canopy and $(\mathrm{e}-\mathrm{h})$ a common-species canopy for four tree species. Pigmented first- and secondorder roots $[1+2 \mathrm{~B}]$ and third- and fourth-order roots $[3+4 \mathrm{~B}]$ represent roots of different root order classes, from root litterbags placed at 10-cm soil depth and harvested after 3,8,14, 19, and 36 months for the own-species canopy placement and after 3, 8, and 14 months under the common-species canopy placement. Error bars represent \pm SE $(n=3$ root litterbags per sampling time, including the different root classes). Note different $y$-axis scales in panels (a)-(d). 
TABLE 4. The effects of root pigmentation on initial tissue chemistry at the start of the litter bag experiment in two temperate tree species.

\begin{tabular}{|c|c|c|c|c|c|c|c|}
\hline Species & $\begin{array}{c}\text { Root } \\
\text { pigmentation }\end{array}$ & $\mathrm{C}$ & $\mathrm{N}$ & Lignin & $\mathrm{Al}$ & $\mathrm{Ca}$ & $\mathrm{Mg}$ \\
\hline \multirow[t]{2}{*}{ Acer pseudoplatanus } & {$[1+2 \mathrm{~W}]$} & $470(3.8)$ & $14.8(0.9)$ & 200 (17) & $0.49(0.0)$ & $5.4(0.4)$ & $3.1(0.3)$ \\
\hline & {$[1+2 \mathrm{~B}]$} & $488(0.2)$ & $15.8(0.4)$ & $227(8.5)$ & $1.15(0.1)$ & $6.2(0.33)$ & $3.1(0.2)$ \\
\hline \multirow[t]{2}{*}{ Tilia cordata } & {$[1+2 \mathrm{~W}]$} & $479(4.4)$ & $15.5(0.2)$ & 289 (29) & $0.61(0.0)$ & $4.1(0.1)$ & $2.7(0.1)$ \\
\hline & {$[1+2 \mathrm{~B}]$} & $490(2.0)$ & $16.3(0.5)$ & 189 (54) & $1.47(0.1)$ & $14.5(0.7)$ & $2.5(0.1)$ \\
\hline
\end{tabular}

Notes: Data are expressed as milligrams per gram (with SE in parentheses; $n=3$ root litterbags per sampling time) of root dry mass of two root pigmentation classes: white first- and second-order roots $[1+2 \mathrm{~W}]$ and pigmented first- and second-order roots $[1+2 \mathrm{~B}]$; pigmented roots are older than white roots.

second-order roots of different pigmentation, $[1+2 \mathrm{~W}]$ and $[1+2 \mathrm{~B}]$ (holding order constant; Table 4). Several parameters linked to rates of tissue decomposition in other studies, including initial root $\mathrm{N}$ and lignin concentration as well as $\mathrm{C}: \mathrm{N}$ and lignin: $\mathrm{N}$ ratios (Silver and Miya 2001), were not clearly affected by either root pigmentation across all species or even within single species (lack of interaction of species and pigmentation; Table 5). However, concentrations of some elements did differ between younger, white $[1+2 \mathrm{~W}]$ and older, brown $[1+2$ B] roots. For example, initial Al concentration was much higher in pigmented roots. For other root tissue chemistry parameters, including initial concentrations of $\mathrm{Ca}$ and $\mathrm{P}$ and $\mathrm{Ca}: \mathrm{Al}$ ratio, the relation to root pigmentation varied by tree species (Table 4). Pigmented roots of $T$. cordata had much higher Ca concentrations than white roots, whereas in $A$. pseudoplatanus, $\mathrm{Ca}$ concentration was similar in white and pigmented roots. Pigmented roots of $T$. cordata had lower $\mathrm{P}$ concentrations than white roots, but in $A$. pseudoplatanus, there was no change in $\mathrm{P}$ concentration with root pigmentation. In T. cordata, pigmented roots had higher Ca:Al ratios than white roots, whereas the pattern was reversed in A. pseudoplatanus (Table 4).

Despite few consistent differences in chemistry, white roots decomposed faster than pigmented roots of the same root order class as hypothesized. Over the 14month observation period, white roots lost $\sim 30 \%$ of their mass, while pigmented roots of the same root order lost only $10 \%$ of their mass (Fig. 4).

The single, negative exponential model described observed rates of decay well across root pigmentation classes, and there was no evidence of two distinct phases of decay during 14 months. The estimated mass remaining fit the actual mass remaining for $[1+2 \mathrm{~W}]$ roots with an $R^{2}=0.91(n=24)$ and for $[1+2 \mathrm{~B}]$ roots with an $R^{2}=0.64(n=24)$. The rate of decay was underestimated for white roots, as indicated by the intercept of $b_{0}=16$, but estimated well for pigmented roots $\left(b_{0}=0.5\right)$. Over the time period of 14 months, the average decomposition constant $(k)$ was 0.28 for $[1+2$ W] roots $\left(R^{2}=0.72\right)$ and was correlated positively with initial $\mathrm{Ca}(P=0.0002)$ and lignin:P ratio $(P=0.0011)$ and negatively with initial $\mathrm{Mg}(P=0.0031$; Table 6). Despite the tight correlation between initial root $\mathrm{Mg}$ and $\mathrm{N}$ (Appendix F), replacement of $\mathrm{Mg}$ by $\mathrm{N}$ in the model did not improve prediction of decomposition rates $\left(R^{2}=\right.$ $0.61)$. In contrast, the decay constant $(k)$ was much lower in $\left[1+2\right.$ B] $\operatorname{roots}\left(k=0.08, R^{2}=0.49\right)$. Decomposition in the pigmented roots was positively related to initial root $\mathrm{C}: \mathrm{N}$ ratio $(P=0.001)$ and negatively related to initial $\mathrm{Mg}$ concentration $(P=$ 0.0016). When both root pigmentation classes were analyzed together $\left(k=0.15, R^{2}=0.47\right)$, decay rate was negatively related to initial $\mathrm{Mg}$ concentration $(P=$ $0.0022)$ as well as to initial $\mathrm{N}(P=0.031)$ and $\mathrm{Al}(P=$ 0.028 ) concentration (Table 6). Excluding or replacing initial root $\mathrm{Mg}$ with initial root $\mathrm{N}$ or $\mathrm{Ca}$ in the combined model did also not improve prediction of decomposition rates $\left(R^{2}=0.35\right.$ in both cases). The combination of root tissue chemistry parameters (lignin:P, $P<0.0009 ; \mathrm{N}, P$ $<0.002$; $\mathrm{Ca}, P<0.034)$ and the categorical parameter, root pigmentation class $(P<0.0031)$, predicted variation in the decomposition constant $\left(k=0.15, R^{2}=0.52\right)$ better than the chemical parameters alone, except for [1 $+2 \mathrm{~W}]$ roots, suggesting that the chemical properties measured could not fully account for variation in tissue quality associated with root pigmentation.

In contrast to the more rapid biomass loss in white than pigmented roots across the two species, $\mathrm{N}$ content

TABLE 5. Probability values from an ANOVA of root pigmentation on initial tissue chemistry at the start of the litterbag experiment in two temperate tree species of initial chemical concentrations or ratios.

\begin{tabular}{lccccccccccc}
\hline \hline \multicolumn{1}{c}{ Factor } & $\mathrm{C}$ & $\mathrm{N}$ & Lignin & $\mathrm{Al}$ & $\mathrm{Ca}$ & $\mathrm{Mg}$ & $\mathrm{P}$ & $\mathrm{C}: \mathrm{N}$ & Lignin:N & Lignin:P & Ca:Al \\
\hline Species & 0.07 & 0.36 & 0.09 & 0.33 & 0.08 & 0.12 & $\mathbf{0 . 0 0 1}$ & 0.59 & 0.18 & 0.99 & 0.72 \\
Root pigmentation & $\mathbf{0 . 0 0 3}$ & 0.26 & 0.57 & $\mathbf{0 . 0 0 0 5}$ & 0.30 & 0.92 & 0.51 & 0.62 & 0.78 & 0.72 & $<\mathbf{0 . 0 0 0 1}$ \\
Species $\times$ root & 0.24 & 0.88 & 0.08 & 0.27 & $\mathbf{< 0 . 0 0 0 1}$ & 0.54 & $\mathbf{0 . 0 4 7}$ & 0.95 & 0.18 & 0.515 & $<\mathbf{0 . 0 0 0 1}$
\end{tabular}

pigmentation

Notes: Roots were of two root pigmentation classes: white first- and second-order roots $[1+2 \mathrm{~W}]$ and pigmented first- and second-order roots $[1+2 \mathrm{~B}]$ of two temperate tree species (Acer pseudoplatanus L. and Tilia cordata Mill.; $n=3$ root litterbags per sampling time). Boldface indicates $P<0.05$; italics indicate $P<0.10$. 
TABLE 4. Extended.

\begin{tabular}{ccccc}
\hline \hline & & & & \\
$\mathrm{P}$ & $\mathrm{C}: \mathrm{N}$ & Lignin:N & Lignin:P & Ca:Al \\
\hline $1.7(0.1)$ & $31(1.8)$ & $14(2)$ & $118(3.8)$ & $11(0.7)$ \\
$1.8(0.1)$ & $31(0.8)$ & $14(0.7)$ & $127(13)$ & $5.3(0.2)$ \\
$2.5(0.1)$ & $31(0.6)$ & $18(1.8)$ & $117(17)$ & $6.8(0.5)$ \\
$2.0(0.1)$ & $30(0.9)$ & $11(3.7)$ & $93(30)$ & $9.9(0.5)$ \\
\hline
\end{tabular}

decreased more rapidly only in white roots of $T$. cordata, but not in those of $A$. platanoides (Fig. 4). In addition, no effect of pigmentation was observed on loss of $\mathrm{Mg}$ and $\mathrm{P}$ over time $(P>0.77$; Appendix $\mathrm{G})$. Only in $T$. cordata did pigmentation influence root $\mathrm{Ca}$ content over the 14 months, with white roots showing a rapid increase of $230 \%$ whereas pigmented roots remained essentially unchanged.

\section{Discussion}

The roots with the greatest likelihood of dying (i.e., with the fastest turnover) are first- and second-order roots (Eissenstat et al. 2000, Wells and Eissenstat 2001, Guo et al. 2008a, b), yet decomposition of these particular root orders has rarely been studied. Some studies have examined decomposition (disappearance) using minirhizotrons, but the effect of different root types (white vs. pigmented, roots of different order) were not addressed (Comas et al. 2000, Ruess et al. 2003). Our analysis of root decomposition, based on differences in structure and function among finest root orders, revealed that among the species studied here, decay rates in these lowest orders were significantly slower than those of higher root orders. These results are in agreement with Fan and Guo (2010), who examined decomposition of different root orders in Larix gmelinii and Fraxinus mandshurica. After 17 months, they observed $\sim 20-30 \%$ mass loss in first- and second-order roots in the two species and $\sim 20-40 \%$ greater mass loss in the third- and fourth-order roots. Other studies that used diameter classes have also indicated that the finest roots decomposed at a slower rate than somewhat coarser roots (McClaugherty et al. 1984, diameter 0-0.5 $\mathrm{mm}$ and 0.5-3 mm; Fahey et al. 1988, diameter 0.6-1 $\mathrm{mm}$ and 1-2.5 mm; Lõhmus and Ivask 1995, diameter $<1 \mathrm{~mm}$ and $<2 \mathrm{~mm}$ ). Yet, in many species, even bulk fine-root samples of a root diameter $<0.5 \mathrm{~mm}$ can contain at least three root orders, with mass biased toward the higher-order roots (Pregitzer et al. 2002). Careful selection of diameter classes to represent different groups of root orders is possible (e.g., Withington et al. 2006) and might be an alternative approach to distinguishing roots of different function; however, it is not clear that the early studies chose their diameter classes along these functional criteria. Where functional criteria are not used, our study suggests that bulk root decomposition studies may overestimate rates of decomposition of the roots that most frequently die. In addition, nutrient dynamics of first- and second-order roots may differ substantially from those of third- and fourth-order roots, especially in the early phases of decomposition: we found more rapid nitrogen loss (despite slower mass loss) in lower-order than in higher-order roots. A more mechanistic understanding of root decomposition and its contribution to ecosystem carbon and nutrient dynamics requires a fundamental shift in experimental methods toward stratifying root samples for decomposition studies along more functionally based criteria such as root order coupled with rootorder-specific understanding of root mortality.

The patterns of decomposition in the different root order classes were opposite what might be expected from $\mathrm{C}: \mathrm{N}$ ratio or root diameter. For most species in our study, initial litter chemistry differed among root orders in a manner similar to what has been previously reported (Pregitzer et al. 2002, Guo et al. 2004, Wang

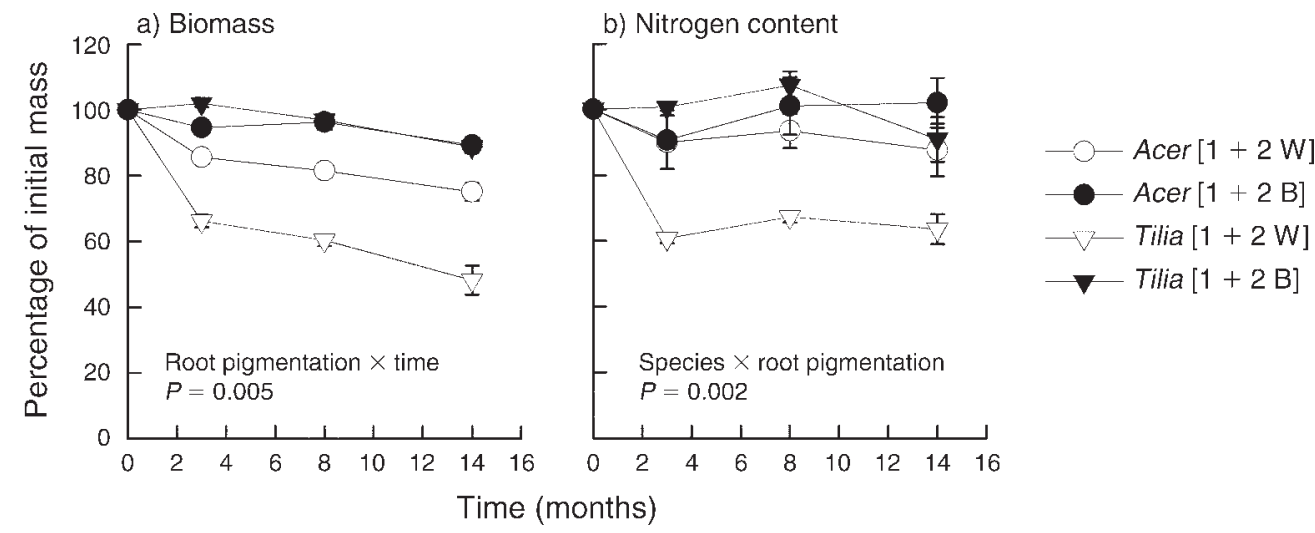

FIG. 4. Effects of root pigmentation on (a) biomass and (b) nitrogen content during decomposition. Data are expressed as the percentage of initial mass or nitrogen under the own-species canopy only, contrasting younger white first- and second-order roots $[1+2 \mathrm{~W}]$ with older pigmented first- and second-order roots $[1+2 \mathrm{~B}]$ in two temperate tree species (Acer pseudoplatanus and Tilia cordata $)$ over a time period of 14 months. Error bars represent $\pm \mathrm{SE}(n=3$ root litterbags per sampling time, including the different root classes). 
TABLE 6. Final models resulting from stepwise regressions of the root decomposition coefficient, $k$, against root chemical characteristics by root pigmentation class for roots in "own" plots.

\begin{tabular}{lllll}
\hline \hline $\begin{array}{c}\text { Fine-root } \\
\text { pigmentation classes }\end{array}$ & $k$ & df & $R^{2}$ & Model equation \\
\hline $\begin{array}{l}\text { Chemical properties only } \\
{[1+2 \mathrm{~W}]}\end{array}$ & 0.28 & 23 & 0.72 & $k=-0.32+0.06 \times(\mathrm{Ca})+0.002 \times(\operatorname{lignin}: \mathrm{P})-0.08 \times(\mathrm{Mg}) \dagger$ \\
{$[1+2 \mathrm{~B}]$} & 0.08 & 23 & 0.49 & $k=-0.43+0.01 \times(\mathrm{C}: \mathrm{N})-0.06 \times(\mathrm{Mg}) \dagger$ \\
$\begin{array}{l}\text { Combined } \\
\begin{array}{l}\text { Root pigmentation class }+ \\
\text { chemical properties }\end{array}\end{array}$ & 0.15 & 47 & 0.47 & $k=0.73-0.1 \times(\mathrm{Mg})-0.07 \times(\mathrm{Al})-0.02 \times(\mathrm{N})$ \\
& & 47 & 0.52 & $k=0.32+0.001 \times($ lignin:P $)-0.03 \times(\mathrm{N})$ \\
\end{tabular}

Notes: Results are separated into fine-root pigmentation classes: white first- and second-order roots, [1+2 W], or pigmented first- and second-order roots, $[1+2 \mathrm{~B}]$, or white and pigmented first- and second-order roots (combined) or root pigmentation classes + chemical properties. All terms included in the models were significant at $P<0.001$. See Methods: Plant material for a description of "own" plots.

$\dagger$ The parameters in the equation could be replaced with (in this order) $\mathrm{Ca}, \mathrm{Mg}$, and $\mathrm{P}$ and result in an $R^{2}$ of 0.70 .

$\$$ The parameter $\mathrm{Mg}$ in the $[1+2 \mathrm{~B}]$ equation could be replaced with the parameter $\mathrm{P}$ remaining negatively related and result in an $R^{2}$ of 0.47 .

et al. 2006, Fan and Guo 2010) with lower C:N ratio, lignin: $\mathrm{N}$, and lignin: $\mathrm{P}$ in finer, lower-order $[1+2 \mathrm{~B}]$ roots compared to coarser, higher-order $[3+4 \mathrm{~B}]$ roots. However, $[3+4 \mathrm{~B}]$ roots with higher $\mathrm{C}: \mathrm{N}$, lignin: $\mathrm{N}$, and lignin:P ratios decomposed faster than $[1+2 \mathrm{~B}]$ roots with lower values of these ratios in three of four species, which is in contrast to past syntheses of leaf litter decomposition (Cornwell et al. 2008).

Initial chemical parameters only partially explained the variation in decomposition among root orders. When $\mathrm{Mg}$ and $\mathrm{P}$ were used as covariates in an ANCOVA of mass loss, root order and the interaction of species and order were still highly significant. One possible explanation for the relatively greater recalcitrance of the first- and second-order, pigmented roots to microbial decomposition is that these roots are typically heavily colonized by mycorrhizal fungi, which may have important chemical consequences for decomposers that are not captured by typical measures (Langley and Hungate 2003, Guo et al. 2008a, Valenzuela-Estrada et al. 2008). Our study species included both arbuscular mycorrhizal (AM) and ectomycorrhizal (ECM) tree species (Withington et al. 2006). Both types of mycorrhizal fungi produce the compound chitin, which may slow rates of decomposition, as found in bulk fine roots (diameter $<1 \mathrm{~mm}$ ) (Langley et al. 2006), despite being rich in $\mathrm{N}$. Whether chitin or some other chemical aspect of mycorrhizal fungi that transcends mycorrhizal type (AM vs. ECM) is the cause for the slower rates of decomposition in pigmented first- and second-order roots than white roots or higher-order roots needs further study, but chitin could be responsible for the relationship between decomposition rate and root $C: N$ ratio being opposite of what has been seen previously for leaf litter. Besides chitin, mycorrhizal colonization can also increase defense-related, secondary antifungal metabolite concentrations (Gadkar et al. 2001, De Deyn et al. 2009). The increase in defense-related compounds could explain the intact root structures in cross sections of pigmented first- and second-order root of $T$. cordata, colonized by ectomycorrhizal fungi, in contrast to the more degraded structures in third- and fourth-order roots after 36 months of decay (Fig. 2).

Another factor that may contribute to the faster decomposition in the higher-order roots is their typically greater role in storage of carbohydrates. Fan and Guo (2010) observed an approximately 10-30\% higher relative concentration of total nonstructural carbohydrates (TNC) in the third- and fourth-order roots than in the first- and second-order roots, depending on species. Within approximately two months of decomposition, TNC concentrations declined by $>50-80 \%$ and no longer differed among orders. These easily degradable sources of carbon may have primed the decomposer community, causing continued faster decomposition in the higher-order roots.

The heterogeneous pattern of $\mathrm{N}$ mineralization and immobilization from fine roots of both groups of root classes contrasted with reported findings that root $\mathrm{N}$ is released linearly during the initial phases of decomposition in root tissues that have $\mathrm{C}: \mathrm{N}$ ratios as high as 50 (Parton et al. 2007). In contrast, we found in our study that pigmented higher-order $[3+4 \mathrm{~B}]$ roots with an initial $\mathrm{C}: \mathrm{N}$ ratio ranging from 25 to 50 exhibited $\mathrm{N}$ immobilization. The root classes of lower-order $[1+2$ $\mathrm{W}]$ and $[1+2 \mathrm{~B}] \operatorname{roots}(\mathrm{C}: \mathrm{N}$ ranging from 24 to 30 ) exhibited either very little change in $\mathrm{N}$ content or $\mathrm{N}$ mineralization. In contrast, Fan and Guo (2010) observed in a relatively nutrient-rich soil in northeastern China that all root orders initially lost $\mathrm{N}$ in the first two months, but the highest-order roots immobilized $\mathrm{N}$ to varying extent in the following months of decomposition. Temporary immobilization of root $\mathrm{N}$ was also reported in decaying roots with diameters less than 1 mm (Lõhmus and Ivask 1995) and less than $2 \mathrm{~mm}$ (Ostertag and Hobbie 1999, Guo et al. 2006, Langley et al. 2006), indicating that bulk fine-root samples may exhibit net release of $\mathrm{N}$ at lower $\mathrm{C}: \mathrm{N}$ ratios than roots separated by order, at least at sites of low soil fertility. One possible explanation for $\mathrm{N}$ immobilization in the early phase of decomposition of higher-order $[3+4 \mathrm{~B}]$ roots in this study is that these roots may have a large 
fraction of their $\mathrm{C}$ compounds in the form of readily degradable starch (Fan and Guo 2010), leading to appreciable mass and $\mathrm{C}$ loss and the immobilization of some microbial $\mathrm{N}$, especially of chitin-rich decomposer fungi. In lower-order roots, there is much less starch and more protein $\mathrm{N}$ for nutrient assimilation. These differences in chemistry of different root orders underscore the importance of branching architecture in studies of root decomposition.

The influence of soil environment, as reflected by comparisons of common- vs. own-species plots, had only modest effects on the patterns of mass and $\mathrm{N}$ in relation to root order among species. Soils of Pinus and Larix plots differed appreciably from those of the common Acer plot. In P. sylvestris, there was evidence of faster decomposition and greater $\mathrm{N}$ immobilization in the higher root orders in the less acidic common plot than in the Pinus plot, possibly a result of higher microbial activity in the common plot.

Among the chemical parameters influencing mass loss of the different root orders, initial $\mathrm{Mg}$ concentration was often correlated with the decay constant. Initial root $\mathrm{Mg}$ concentration probably did not directly influence decomposition but was correlated with a chemical parameter that did, such as its general negative correlation with $\mathrm{Ca}$ :Al ratio (Appendix $\mathrm{C}$ ). Thus, low $\mathrm{Ca}$ :Al ratio might more likely be the reason for inhibited microbial activity and slower rates of decomposition in some species, as found by Vogt et al. (1987). Initial P concentration and its influence on decomposition rates were expected, since many studies had already shown the importance of this parameter on the decay of leaf litter (Berg et al. 1993). Because root $\mathrm{Mg}$ and $\mathrm{P}$ concentrations as well as root order were significant $(P$ $<0.001$ for all three effects, Table 4 ), we conclude that these nutrients were contributing to variation in percentage mass loss largely independent of some other factor that was associated with root order that also influenced decomposition.

Even within root orders, additional factors besides root chemistry may contribute significant variation to root decomposition. Root pigmentation did not influence nutrient or lignin content among white and pigmented first- and second-order roots but did result in different decomposition rates. Young, white roots consistently had faster rates of decomposition than older, pigmented roots of the same order. Since pigmentation is associated with accumulation of condensed tannins and other accumulated defenses (Wells and Eissenstat 2003), white roots may be readily consumed by microbial decomposers. For instance, a recent study showed that herbivores such as Collembola predominately feed on white fine roots and root hairs, rather than soil microbes (Endlweber et al. 2009). Furthermore, when estimates of root mortality, such as those derived using minirhizotrons, are combined with estimates of decomposition, it may be important to distinguish between the populations of roots that are young and still white at the time of death from the remainder of the root population that is pigmented at death. Where white roots die (Wells and Eissenstat 2001, Anderson et al. 2003), the cycling of $\mathrm{C}$ and nutrients is likely to be rapid. In general, it is not clear whether the delay in pigmentation of the youngest and most vulnerable roots is an unavoidable consequence of development, or whether, as hypothesized for some tropical forest leaves that also delay pigmentation, expensive chemical investment is delayed until roots become slightly more physically recalcitrant and thus less physically vulnerable (Kursar and Coley 1992).

Root pigmentation or root order always described a substantial portion of the variance in the rate of percentage mass loss when the other chemical traits were used as covariates, indicating key factors associated with the influence of pigmentation and order on decomposition were not measured. Other chemical and structural properties such as concentrations of nonstructural carbohydrates, soluble phenolics, and chitin need to be explored to better understand more mechanistically how root pigmentation and order affect decomposition. Still, some of our findings are consistent with results of a study at the same site that compared decomposition of leaf litter with that of bulk fine roots (diameter $<2 \mathrm{~mm}$ ) across 11 species (Hobbie et al. 2010). They found that species with higher specific root length (SRL; root length per unit dry mass) (thinner) roots decomposed more slowly than species with lower SRL (thicker) roots, similar to our findings for roots of different order within the same species.

While the present study clearly shows the relative importance of root pigmentation and root order on decomposition, absolute decomposition rates in the field may differ from what are reported here. The use of dried fine roots can lead to overestimates of rates of decomposition and nutrient cycling (Ludovici and Kress 2006). In addition, the use of mesh litter bags allowed only microbial decay and resulted in disturbed rhizospheres, likely leading to underestimates of rates of root decomposition (Dornbush et al. 2002), especially for the vulnerable white first- and second-order roots (Pregitzer et al. 1997, Stevens et al. 2002, Withington et al. 2006). The loss of only $20 \%$ of first- and second-order root mass after 36 months in several of the species in this study, for example, may underestimate root decomposition in situ where soil fauna and microbial-rich rhizospheres contribute to decomposition. Further study is necessary to determine to what extent this might bias our observations that the lower root orders decomposed slower than the higher root orders or that white roots decompose faster than pigmented roots. Lastly, the use of nursery-grown seedlings also might affect absolute patterns but not likely relative patterns in at least nutrient concentrations between root order classes.

In summary, root decomposition can be influenced by root pigmentation and root order, but previous root decomposition studies have rarely considered this fine- 
scale heterogeneity in fine roots. Pigmented first- and second-order roots that can account for $\sim 75 \%$ of the total length of fine roots (Pregitzer et al. 2002) may decompose more slowly but lose elements such as $\mathrm{N}$ more readily compared to the higher-order third- and fourth-order roots. These differences were generally consistent across diverse species. While it is logistically much easier to include all roots below a certain diameter (e.g., $<2 \mathrm{~mm}$ ) as a single class, this approach masks important differences in tissue chemistry and known differences in the relative contribution of different root orders to the detrital pool (Pregitzer et al. 2002, Guo et al. 2008a, b, Valenzuela-Estrada et al. 2008). Moreover, classical hypotheses about the chemical controls of decomposition dynamics were in some cases opposite to observed responses. Thus, there is always a trade-off between gaining functional information that comes from analyzing roots of different orders and the enormous labor required to separate roots at this level. In order to understand the contributions of root turnover to $\mathrm{C}$ and nutrient cycling, we need to improve our understanding of not only the rates of root turnover of different root orders, but also how the different root classes decompose.

\section{ACKNOWLEDGMENTS}

We thank Anna Woznica, Artur Stefanski, and Damian Rybak for data collection at the site, Iwo Galecki, Director of the Siemianice Experimental Forest District, for his support with accommodation at the local forest district office, Martin Goffinet of Cornell University for microtechnical and photographical assistance, and the members of the Eissenstat laboratory for helpful discussions, especially Luke McCormack for his help with sample preparations and Kevin Mueller for his comments on the manuscript. We also appreciate the helpful reviews of two anonymous reviewers for improving the manuscript. We are grateful for the identification of mycorrhizal morphotypes by the Laboratory of Mycorrhizal Research of the Institute of Dendrology, Kórnik, Poland. NSF contributed to the work through the following grants: DEB 01298944 (PSU), IOB 0613832 (PSU), DEB 0816935 (PSU), and DEB 0128958 (UMN). D. D. Archibald's contributions to the root characterization aspects of this study were partly supported by the Center for LignoCellulose Structure and Formation, an EFRC funded by U.S. DOE BES (award DE-SC0001090). This research was also supported by the Department of Horticulture, Ecology IGDP, and the College of Agriculture Science at Penn State University.

\section{Literature Cited}

Anderson, L. J., L. H. Comas, A. N. Lakso, and D. M Eissenstat. 2003. Multiple risk factors in root survivorship: a 4-year study in Concord grape. New Phytologist 158:489501.

Bauerle, T. L., D. M. Eissenstat, J. Granett, D. M. Gardner, and D. R. Smart. 2007. Consequences of insect herbivory on grape fine root systems with different growth rates. Plant, Cell and Environment 30:786-795.

Berg, B. 1984. Decomposition of root litter and some factors regulating the process: long-term root litter decomposition in a Scots pine forest. Soil Biology and Biochemistry 16:609617.

Berg, B., et al. 1993. Litter mass loss rates in pine forests of Europe and eastern United States: some relationships with climate and litter quality. Biogeochemistry 20:127-159.
Brinkmann, K., L. Blaschke, and A. Polle. 2002. Comparision of different methods for lignin determination as a basis for calibration of near-infrared reflectance spectroscopy and implications of lignonproteins. Journal of Chemical Ecology 28:2483-2501.

Brundrett, M. C., G. Murase, and B. Kendrick. 1990. Comparative anatomy of roots and mycorrhizae of common Ontario trees. Canadian Journal of Botany 68:551-578.

Caldwell, M. M. 1987. Plant architecture and resource competition. Pages 164-179 in E. D. Schulze and H. Zwölfer, editors. Ecological studies. Springer-Verlag, Berlin, Germany.

Chen, H., M. E. Harmon, J. Sexton, and B. Fasth. 2002. Fineroot decomposition and $\mathrm{N}$ dynamics in coniferous forests of the Pacific Northwest, USA. Canadian Journal of Forest Research 32:320-331.

Comas, L. H., D. M. Eissenstat, and A. N. Lakso. 2000. Assessing root death and root system dynamics in a study of grape canopy pruning. New Phytologist 147:171-178.

Cornwell, W. K., et al. 2008. Plant species traits are the predominant control on litter decomposition rates within biomes worldwide. Ecology Letters 11:1065-1071.

Dauer, J. M., J. Chorover, O. A. Chadwick, J. Oleksyn, M. G. Tjoelker, S. E. Hobbie, P. B. Reich, and D. M. Eissenstat. 2007. Controls over leaf and litter calcium concentrations among temperate trees. Biogeochemistry 86:175-187.

De Deyn, G. B., A. Biere, W. H. van der Putten, R. Wagenaar, and J. N. Klironomos. 2009. Chemical defense, mycorrhizal colonization and growth responses in Plantago lanceolata L. Oecologia 160:433-442.

Dornbush, M. E., T. M. Isenhart, and J. W. Raich. 2002. Quantifying fine-root deomposition: an alternative to buried litterbags. Ecology 83:2985-2990.

Eissenstat, D. M., and A. Volder. 2005. The efficiency of nutrient acquisition over the life of a root. Pages 185-220 in H. BassiriRad, editor. Nutrient acquisition by plants: an ecological perspective. Springer-Verlag, New York, New York, USA.

Eissenstat, D. M., C. E. Wells, R. D. Yanai, and J. L. Whitbeck. 2000. Building roots in a changing environment: implications for root longevity. New Phytologist 147:33-42.

Endlweber, K., L. Ruess, and S. Scheu. 2009. Collembola switch diet in presence of plant roots thereby functioning as herbivores. Soil Biology and Biochemistry 41:1151-1154.

Engler, A. 1903. Untersuchungen über das Wurzelwachstum der Holzarten. Mittelungen der Schweizerischen Centralanstalt für das forstliche Versuchswesen 7:247-317.

Esau, K. 1965. Plant anatomy. Second edition. John Wiley and Sons, New York, New York, USA.

Fahey, T. J., J. W. Hughes, M. Pu, and M. A. Arthur. 1988. Root decomposition and nutrient flux following whole-tree harvest of northern hardwood forest. Forest Science 34:744768.

Fan, P., and D. Guo. 2010. Slow decomposition of lower order roots: a key mechanism of root carbon and nutrient retention in the soil. Oecologia. [doi: 10.1007/s00442-009-1541-4]

Fitter, A. H. 1982. Morphometric analysis of root systems: application of the technique and influence of soil fertility on root system development in two herbaceous species. Plant, Cell and Environment 5:313-322.

Gadkar, V., R. David-Schwartz, T. Kunik, and Y. Kapulnik. 2001. Arbuscular mycorrhizal fungal colonization: factors involved in host recognition. Plant Physiology 127:14931499.

Guo, D. L., H. Li, R. J. Mitchell, W. X. Han, J. J. Hendricks, T. J. Fahey, and R. L. Hendrick. 2008a. Anatomical traits associated with absorption and mycorrhizal colonization are linked to root branch order in twenty-three Chinese temperate tree species. New Phytologist 180:673-683.

Guo, D. L., R. J. Mitchell, and J. J. Hendricks. 2004. Fine root branch orders respond differentially to carbon source-sink 
manipulations in a longleaf pine forest. Oecologia 140:450457.

Guo, D. L., R. J. Mitchell, J. M. Withington, P. P. Fan, and J. J. Hendricks. 2008b. Endogenous and exogenous controls of root lifespan, mortality and nitrogen flux in a longleaf pine forest: root branch order predominates. Journal of Ecology 96:737-745.

Guo, L. B., M. J. Halliday, and R. M. Gifford. 2006. Fine root decomposition under grass and pine seedlings in conrtrolled environmental conditions. Applied Soil Ecology 33:22-29.

Hishi, T. 2007. Heterogeneity of individual roots within the fine root architecture: causal links between physiological and ecosystem functions. Journal of Forest Research 12:126-133.

Hobbie, S. E., M. Ogdahl, J. Chorover, O. A. Chadwick, J. Oleksyn, R. Zytkowiak, and P. B. Reich. 2007. Tree species effects on soil organic matter dynamics: the role of soil cation composition. Ecosystems 10:999-1018.

Hobbie, S. E., J. Oleksyn, D. M. Eissenstat, and P. B. Reich. 2010. Fine root decomposition rates do not mirror those of leaf litter among temperate tree species. Oecologia 162:505513.

Hobbie, S. E., P. B. Reich, J. Oleksyn, M. Ogdahl, R. Zytkowiak, C. M. Hale, and P. Karolewski. 2006. Tree species effects on decomposition and forest floor dynamics in a common garden. Ecology 87:2288-2297.

Iiyama, L., and A. F. A. Wallis. 1988. An improved acetyl bromide procedure for determining lignin in woods and wood pulps. Wood Science and Technology 22:271-280.

Jackson, R. B., H. A. Mooney, and E.-D. Schulze. 1997. A global budget for fine root biomass, surface area, and nutrient contents. Proceedings of the National Academy of Sciences USA 94:7362-7366.

King, J. S., T. J. Albaugh, H. L. Allen, M. Buford, B. R. Strain, and P. Dougherty. 2002. Below-ground carbon input to soil is controlled by nutrient availability and fine root dynamics in loblolly pine. New Phytologist 154:389-398.

Krueger, K., and J. M. Trappe. 1967. Food reserves and seasonal growth of Douglas-fir seedlings. Forest Science 13: 192-202.

Kursar, T. A., and P. D. Coley. 1992. Delayed development of the photosynthetic apparatus in tropical rain forest species. Functional Ecology 6:411-422.

Langley, J. A., S. K. Chapman, and B. A. Hungate. 2006. Ectomycorrhizal colonization slows root decomposition: the post-mortem fungal legacy. Ecology Letters 9:955-959.

Langley, J. A., and B. A. Hungate. 2003. Mycorrhizal controls on belowground litter quality. Ecology 84:2302-2312.

Leuschner, C., C. Heinz, R. Icke, K. Hartmann, N. D. Effinger, and L. Schreiber. 2003. Chemical composition of the periderm in relation to in situ water absorption rates of oak, beech and spruce fine roots. Annals of Forest Science 60:763-772.

Leuschner, C., D. Hertel, I. Schmid, O. Koch, A. Muhs, and D. Hölscher. 2004. Stand fine root biomass and fine root morphology in old-growth beech forests as a function of precipitation and soil fertility. Plant and Soil 258:43-56.

Lõhmus, K., and M. Ivask. 1995. Decompostion and nitrogen dynamics of fine roots of Norway spruce (Picea abies (L.) Karst.) at different sites. Plant and Soil 168-169:89-94.

Ludovici, K. H., and L. W. Kress. 2006. Decomposition and nutrient release from fresh and dried pine roots under two fertilizer regimes. Canadian Journal of Forest Research 36: $105-111$.

Lyr, H., and G. Hoffmann. 1967. Growth rates and growth periodicity of tree roots. International Review of Forestry Research 2:181-206.

Massicotte, H. B., L. H. Melville, R. L. Peterson, and R. Molina. 1999. Biology of the ectomycorrhizal fungal genus, Rhizopogon IV: comparative morphology and anatomy of ectomycorrhizas synthesized between Rhizopogon species on ponderosa pine (Pinus ponderosa). New Phytologist 142:355370.

McClaugherty, C. A., J. D. Aber, and J. M. Melillo. 1984. Decomposition dynamics of fine roots in forested ecosystems. Oikos 42:378-386.

McKenzie, B. E., and C. A. Peterson. 1995a. Root browning in Pinus banksiana Lamb. and Eucolyptus piluslaris Sm. 1.: anatomy and permeability of the white and tannin zones. Botanica Acta 108:127-137.

McKenzie, B. E., and C. A. Peterson. 1995b. Root browning in Pinus banksiana Lamb. and Eucalyptus pilularis Sm. 2.: anatomy and permeability of the cork zone. Botanica Acta 108:138-143.

O'Brien, T. P., N. Feder, and M. E. McCully. 1968. Polychromatic staining of plant cell walls by toluidine blue O. Protoplasma 59:367-373.

Ostertag, R., and S. E. Hobbie. 1999. Early stages of root and leaf decomposition in Hawaiian forests: effects of nutrient availability. Oecologia 121:564-573.

Parton, W., W. L. Silver, I. C. Burke, L. Grassens, M. E. Harmon, W. S. Currie, J. Y. King, E. C. Adair, L. A. Brandt, S. C. Hart, and B. Fasth. 2007. Global-scale similarities in nitrogen release patterns during long-term decomposition. Science 315:361-364.

Peterson, C. A., D. E. Enstone, and J. H. Taylor. 1999. Pine root structure and its potential significance for root function. Plant and Soil 217:205-213.

Pregitzer, K. S., J. L. DeForest, A. J. Burton, M. F. Allen, R. W. Ruess, and R. L. Hendrick. 2002. Fine root architecture of nine North American trees. Ecological Monographs 72:293-309.

Pregitzer, K. S., M. E. Kubiske, C. K. Yu, and R. L. Hendrick. 1997. Relationships among root branch order, carbon and nitrogen in four temperate species. Oecologia 111:302-308.

Reich, P. B., J. Oleksyn, J. Modrzynski, P. Mrozinski, S. E. Hobbie, D. M. Eissenstat, J. Chorover, O. A. Chadwick, C. M. Hale, and M. G. Tjoelker. 2005. Linking litter calcium, earthworms and soil properties: a common garden test with 14 tree species. Ecology Letters 8:811-818.

Resendes, M. L., D. R. Bryla, and D. M. Eissenstat. 2008. Early events in the life of apple roots: variation in root growth rate is linked to mycorrhizal and nonmycorrhizal fungal colonization. Plant and Soil 313:175-186.

Ruess, R. W., R. L. Hendrick, A. J. Burton, K. S. Pregitzer, B. Sveinbjornsson, M. F. Allen, and G. E. Maurer. 2003. Coupling fine root dynamics with ecosystem carbon cycling in black spruce forests of interior Alaska. Ecological Monographs 73:643-662.

Silver, W. L., and R. K. Miya. 2001. Global patterns in root decomposition: comparisons of climate and litter quality effects. Oecologia 129:407-419.

Soukup, A., J. Malá, M. Hrubcová, J. Kálal, O. Votrubová, and M. Cvikrová. 2004. Differences in anatomical structure and lignin content of roots of pedunculate oak and wild cherry-tree plantlets during acclimation. Biologia Plantarum 48:481-489.

Stevens, G. N., R. H. Jones, and R. J. Mitchell. 2002. Rapid fine root disappearance in a pine woodland: a substantial carbon flux. Canadian Journal of Forest Research 32:22252230.

Valenzuela-Estrada, L. R., J. H. Richards, A. Diaz, and D. M. Eissenstat. 2009. Patterns of nocturnal rehydration in root tissues of Vaccinium corymbosum L. under severe drought conditions. Journal of Experimental Botany 60:1241-1247.

Valenzuela-Estrada, L. R., V. Vera-Caraballo, L. E. Ruth, and D. M. Eissenstat. 2008. Root anatomy, morphology, and longevity among root orders in Vaccinium corymbosum (Ericaceae). American Journal of Botany 95:1506-1514.

Vogt, K. A., R. Dahlgren, F. Ugolini, D. Zabowski, E. E. Moore, and R. Zasoski. 1987. Aluminum, Fe, Ca, Mg, K, $\mathrm{Mn}, \mathrm{Cu}, \mathrm{Zn}$ and $\mathrm{P}$ in above- and belowground biomass. I. 
Abies amabilis and Tsuga mertensiana. Biogeochemistry 4 277-294.

Volder, A., D. R. Smart, A. J. Bloom, and D. M. Eissenstat. 2005. Rapid decline in nitrate uptake and respiration with age in fine lateral roots of grape: implications for root efficiency and competitive effectiveness. New Phytologist 165: 493-502.

Wang, Z. Q., D. L. Guo, X. R. Wang, J. C. Gu, and L. Mei. 2006. Fine root architecture, morphology, and biomass of different branch orders of two Chinese temperate tree species. Plant and Soil 288:155-171.

Wells, C. E., and D. M. Eissenstat. 2001. Marked differences in survivorship among apple roots of different diameters. Ecology 82:882-892.
Wells, C. E., and D. M. Eissenstat. 2003. Beyond the roots of young seedlings: the influence of age and order on fine root physiology. Journal of Plant Growth Regulation 21:324-334.

Wieder, R. K., and G. E. Lang. 1982. A critique of the analytical method used in examining decomposition data obtained from litter bags. Ecology 63:1636-1642.

Withington, J. M., A. D. Elkin, B. Bulaj, J. Olesinski, K. N. Tracy, T. J. Bouma, J. Oleksyn, L. J. Anderson, J. Modrzynski, P. B. Reich, and D. M. Eissenstat. 2003. The impact of material used for minirhizotron tubes for root research. New Phytologist 160:533-544.

Withington, J. M., P. B. Reich, J. Oleksyn, and D. M. Eissenstat. 2006. Comparison of structure and life span in roots and leaves among temperate tree species. Ecological Monographs 76:381-397.

\section{APPENDIX A}

Percentage of ectomycorrhizal morphotype colonization present on root systems of three temperate tree species (Tilia cordata Mill., Larix decidua Mill., and Pinus sylvestris L.) collected from local nurseries on the root order class pigmented, lower first- and second-order fine roots, by the Rudawska Laboratory, Institute of Dendrology, Kornik, Poland (Ecological Archives M081-004A1).

\section{APPENDIX B}

Initial tissue chemistry of pigmented first- and second-order fine roots [1 $+2 \mathrm{~B}]$ and third- and fourth-order fine roots [3+ $4 \mathrm{~B}]$ from 1-yr-old ingrowth cores (August 2007) from three plots of each of four temperate tree species (Acer pseudoplatanus L., Tilia cordata Mill., Larix decidua Mill., and Pinus sylvestris L.) at the common garden "Morawina" in the Siemianice Experimental Forest, Poland (Ecological Archives M081-004-A2).

\section{APPENDIX C}

Correlation matrices of initial root tissue chemistry for pigmented first- and second-order roots, pigmented third- and fourthorder roots, and combined pigmented first-, second-, third-, and fourth-order roots of the root-order experiment (Ecological Archives M081-004-A3).

\section{APPENDIX D}

Cross sections of pigmented first- and second-order roots and third- and fourth-order roots of Acer pseudoplatanus, Tilia cordara, Larix decidua, and Pinus sylvestris after 19 months of decomposition (Ecological Archives M081-004-A4).

\section{APPENDIX E}

Effect of root branching order on $\mathrm{P}, \mathrm{Mg}$, and Ca content during decomposition under "own" and common species canopies (Ecological Archives M081-004-A5).

\section{APPENDIX F}

Correlation matrices of initial root tissue chemistry for white first- and second-order roots and pigmented first- and second-order roots of the root pigmentation experiment (Ecological Archives M081-004-A6).

\section{APPENDIX G}

Effects of root pigmentation of first- and second-order roots on $\mathrm{P}, \mathrm{Mg}$, and Ca content during decomposition under the "own" canopy species (Ecological Archives M081-004-A7). 